\title{
Ancient Greek Nomos and Modern Legal Theory: A Reappraisal
}

\author{
Lukas van den Berge
}

Thanos Zartaloudis, The Birth of Nomos (Edinburgh: Edinburgh University Press, 2019), xli + 485 pp.

Johan van der Walt, The Concept of Liberal Democratic Law (London: Routledge 2019), xiv + 267 pp.

\section{Introduction}

In law and philosophy, it was once not uncommon to return to the ancient Greeks in order to address modern legal and philosophical problems. ${ }^{1}$ Carl Schmitt, for example, followed the intellectual currents of his time as he based his new ways of thinking about law and politics for an important part on the re-evaluation and appropriation of the ancient Greek tradition. ${ }^{2}$ Well-known, for example, is Schmitt's controversial interpretation of Pindar's fragment $169 \mathrm{a}$ - the poem in which Pindar famously proclaims that 'law [nomos] is king of all'. ${ }^{3}$ Perhaps even better known is Schmitt's obsession with the proem of Homer's Odyssey. Schmitt's tombstone reads KAI NOMON ETN $\Omega$ - his own preferred reading of one of the Odyssey's opening verses that relies on dubious philology but on which Schmitt nevertheless insisted as it would bolster his legal and political theory. ${ }^{4}$ As a clear sign of his intense engagement with the ancient Greeks, Schmitt's reading of the Homeric

1 Perhaps, this is particularly true for a German philosophical tradition that stretches from Schelling, Hegel and Hölderlin via Nietzsche and Heidegger to Adorno, Strauss, Arendt and many others. In all their differences, these thinkers all share the idea that the problems of modernity should somehow be confronted by reconsidering the ancient Greek tradition and rethinking our relation to it. See, e.g., Dennis J. Schmidt, The Germans and Other Greeks (Bloomington: Indiana University Press, 2001) and Johann Chapoutot, Greeks, Romans, Germans (Berkeley: University of California Press, 2016), with many further references.

2 Katerina Stergiopoulou, 'Taking “Nomos”: Carl Schmitt's Philology Unbound', 149 (2014): 95-122.

3 Carl Schmitt, The Nomos of the Earth in the International Law of the Jus Publicum Europaeum, trans. Gary Ulmen (New York: Telos Press, 2006), 67-72. See also Lukas van den Berge, 'Law, King of All: Schmitt, Agamben, Pindar', Law and Humanities 13 (2019): 198-222, with further references.

4 Schmitt, The Nomos of the Earth, 76-78. See also Carl Schmitt, 'Appropriation/Distribution/Production', included as an appendix in Schmitt, Nomos of the Earth, 324-335. In the third verse of Homer's Odyssey (pollōn d' anthrōpōn iden astea kai voon egnō), Schmitt replaces noos by nomos ('The cities of many men he saw and he recognized their nomos'). See Stergiopoulou, 'Taking "Nomos"', 119-122 for an extensive analysis of the dubious nature of that conjecture. 
verse was also embroidered on the table cloths offered to his diner guests at his post-war home in Plettenberg. ${ }^{5}$

Recently, two books have appeared that once again venture to re-investigate modern law and philosophy's ancient Greek underpinnings. And again, the notion of nomos plays a central role. Firstly, Thanos Zartaloudis has published a remarkable study in which he delves into the manifold meanings of that ancient Greek word. Far surpassing Schmitt in philological depth and acumen, Zartaloudis offers us an extraordinarily rich analysis of the polyvalent forms and uses of nomos from the age of Homer up to the days of Socrates - the classical period in which nomos would finally come to acquire its sense of an enacted legal norm ('law') or binding social convention ('custom'). Secondly, nomos is of central importance in Johan van der Walt's recent book on the intertwined modern notions of liberal democracy and the rule of law - referred to by Van der Walt as the concept of liberal democratic law. For Van der Walt, the analysis of ancient Greek nomos and its long and tortuous reception history in western thought is crucial for a proper understanding of what the modern concept of liberal democratic law entails and how it could be saved for the future.

\section{The birth of nomos: philosophy and philology}

What is nomos? In order to find answers to that question, Zartaloudis undertakes a philological tour de force that is probably without precedence in the history of legal scholarship. To a general philosophical audience, nomos is perhaps best known as a term opposed to physis (nature) in the so-called physis-nomos debate that came to occupy so many writers and thinkers since the time of Socrates and the sophists. ${ }^{6}$ In contrast to a natural domain that is beyond human control, nomos would refer to what is artificially contrived. Most commonly, the antithesis was invoked in the legal and the political sphere. There, nomos is most importantly used in order to denote a human convention or an enacted law. In presocratic sources, however, nomos and its cognate terms are often used in ways in which the idea of a legal or customary norm seems far removed or even entirely absent. ${ }^{7}$ It is precisely to those manifold presocratic meanings of nomos - to its birth, so to speak, in archaic and early classical Greece - that Zartaloudis directs his attention.

5 Christian Meier, 'Zu Carl Schmitts Begriffsbildung', in Complexio Oppositorum über Carl Schmitt, ed. Helmut Quaritsch (Berlin: Duncker \& Humblot, 1988): 553; Stergiopoulou, 'Taking “Nomos”', 121 n. 72 .

6 An important source in this regard is still Felix Heinimann, Nomos und Physis: Herkunft und Bedeutung einer Antithese im griechischen Denken des 5. Jahrhunderts (Basel: Reinhart, 1945). See also William Guthrie, A History of Greek Philosophy III: The Sophists (Cambridge: Cambridge University Press, 1971), 55-134 and Mauro Bonazzi, The Sophists (Cambridge: Cambridge University Press, 2020), 65-95, with further references.

7 An important study on the shift of meaning of nomos at the dawn of the classical era is Martin Ostwald, Nomos and the Beginnings of the Athenian Democracy (Oxford: Clarendon Press, 1969). 
Before going into Zartaloudis' analysis of the presocratic semantics of nomos, it is useful to recapitulate just very briefly what Schmitt had to say on that matter. As Schmitt explains most reputedly in his The Nomos of the Earth in the International Law of the Jus Publicum Europaeum, nomos is the nominalization - the nomen actionis - of the Greek verb nemein. ${ }^{8}$ In classical sources, that verb refers either to some act of distribution (to deal out, to distribute) or, in a markedly distinct sense, to the herding of cattle (to graze, to pasture). In Schmitt's philological imagination, however, such meanings are only derivatives of the verb's original sense of spatial ordering. As Schmitt has it, nemein shares a linguistic root with German nehmen (to take, to appropriate). In its original sense, nomos would refer to the appropriation of land (Landnahme) as the constitutive act of spatial ordering that conceptually precedes the moral and legal order that follows from it. ${ }^{9}$ As such, Schmitt's reconstruction of the archaic meaning of nomos aims to unveil the anormative underpinnings of law that normative jurisprudence tends to shield from view. ${ }^{10}$

Of course, Schmitt is well aware that his philological speculations are open to criticism. That does not refrain him, however, from insisting on his claims with characteristic fervour. For Schmitt, all those difficult philological discussions are totally beside the point. Instead, as he writes, he is 'concerned with legal and theoretical constitutional matters', ${ }^{11}$ using philology in order to throw new light on law in ways that are not tied to any detailed semantic or etymological analysis. ${ }^{12}$ In that regard, the approach taken by Zartaloudis is very different. As Zartaloudis indicates in the elaborate preface to this book, his aim is to assemble a genealogical history of nomos that is more or less independent of the preoccupations of modern legal theory (p. xxi). Instead of reprojecting modern notions of law on the "birth of nomos' in archaic and early classical Greece, the idea of his approach is to do utmost justice to the different uses of nomos as they emerge from the available sources. As it turns out, that approach ultimately enriches our understanding of nomos in ways that far offset Schmitt's overly confident handling of the term.

\section{Nómos and nomós}

One of the philological complications totally ignored by Schmitt is that the history of nomos is actually a history of two words: paroxytone nómos (i.e., nomos with a pitch accent on the penultimate syllable) and oxytone nomós (i.e., nomos with a pitch accent on the final syllable). Zartaloudis, however, rightly takes this important difference as a starting point for further investigations. It is only paroxytone nómos

8 Schmitt, Nomos of the Earth, 70. See also Carl Schmitt, 'Nomos-Nahme-Name', included as an appendix in Schmitt, Nomos of the Earth, 341-342 and Schmitt, 'Appropriation/Distribution/ Production', 324-327.

9 Schmitt, Nomos of the Earth, 70.

10 Martin Loughlin, 'Nomos' in Law, Liberty and the State: Oakeshott, Hayek and Schmitt on the Rule of Law, ed. David Dyzenhaus and Thomas Pole (Cambridge: Cambridge University Press, 2015), 69-71.

11 Schmitt, 'Appropriation/Distribution/Production', 324 n. 1.

12 Cf., e.g., Stergiopoulou, 'Taking “Nomos"', 97; Thomas Schestag, 'Namen nehmen: Zur Theorie des Namens bei Carl Schmitt', Modern Language Notes 122 (2007): 559-562. 
that would finally come to be understood as 'law' or 'custom'. Oxytone nomós usually refers to a 'place of pasturage' and, according to a later metaphorical sense, sometimes also to a 'province' or a 'sphere of command'. It is generally believed by linguists that nómos and nomós go back to distinct, but linked semantic roots that finally got mixed up in their many uses. ${ }^{13}$ The dual, but related roots of nomos are also present in nemein as the verb from which both nómos and nomós clearly derive. Whereas nomós is most obviously related to nemein in its pastoral sense (to graze, to pasture), nómos is most clearly associated with nemein as an act of distribution (to deal out, to distribute).

In what is probably the best and certainly most original part of his book, Zartaloudis investigates the many uses of nomos and its family of related words in the epics of Homer. In first instance, the extensive attention paid to 'Homeric nomos' may certainly come as a surprise. The oldest attestation of paroxytone nómos is in post-Homeric poetry, where we encounter it in Hesiod's Works and Days. ${ }^{14}$ As we have seen, the absence of nómos in the Homeric epics does not refrain Carl Schmitt from reading that word - surely mistakenly - in the opening of Homer's Odyssey. ${ }^{15}$ But Zartaloudis' approach to Homeric nomos is much more sophisticated. Whereas nómos is only of later date, the Homeric use of nemein as an act of distribution is actually quite abundant. The same goes for nemein in its pastoral sense and also for oxytone nomós as the noun that derives from it. It is to those words and their broader semantic fields that Zartaloudis invites us to direct our attention.

Zartaloudis' investigations into Homeric nomos start out from the analysis of nemein (to distribute) in the context of feasts and sacrifices, where it is used especially in relation with the ritual or semi-ritual distribution of wine, bread and, most importantly, meat. In the archaic Greek world, feasts are sacred occasions that usually follow a religious sacrifice. ${ }^{16}$ In the Homeric epics, examples abound of feasts at which the sacrificial meat is carefully carved up in portions and distributed among the participants. ${ }^{17}$ It is usually found to be important that these portions are equal, but there are also many cases in which the best portions are given to those whose high social status or extraordinary character seems to deserve such special treatment. For Zartaloudis, the standard Homeric use of nemein to describe the distribution of meat in festive contexts seems to corroborate the idea - earlier suggested by Jan Bremmer and others - that, at least for an important part, nómos as the word that would later be understood as 'law' or 'custom' seems to have referred originally to the right order of sacrificial distribution. ${ }^{18}$

13 Emmanuel Laroche, Histoire de la racine nem- en grec ancien (Paris: Klincksieck, 1949).

14 Hesiod, Works and Days 276; 388. See, e.g., Michael Gagarin, 'The poetry of justice: Hesiod and the origins of Greek law', Ramus 21 (1992): 61-78.

15 Cf., e.g., Stergipoulou, 'Taking "Nomos"', 119-122.

16 Floris van den Eijnde, 'Feasting and Polis Institutions: An Introduction', in Feasting and Polis Institutions, ed. Floris van den Eijnde, Rolf Strootman and Josine Blok (Leiden: Brill, 2018), 1-27.

17 See, e.g., Iliad 9.127; Iliad 24.626; Odyssey 14.436; Odyssey 20.252-253.

18 Jan Bremmer, 'Greek normative animal sacrifice', in A Companion to Greek Religion, ed. Daniel Ogden (Boston: Blackwell, 2007), 132-44. 
Schmitt's association of nemein and nomos with German nehmen and Landnahme is dealt with most explicitly by Zartaloudis in a chapter that is aptly called 'The Nomos of the Land', obviously referring to Schmitt's famous book on international law with more or less the same title. Especially in Homer, nemein in the middle voice (nemesthai) is frequently used in the sense of 'to possess' or 'to hold', most particularly of a piece of land. It is widely agreed upon among linguists that such use is associated with the reflexive and passive meanings that are generally attributed to the middle voice. Hence, 'to distribute among themselves' or 'to be distributed' would have developed into the distinct use of nemesthai as 'to have and hold as one's portion' and hence, with a piece of land as its direct object, also as 'to dwell in, to inhabit'. ${ }^{19}$ As such, it is clear that 'the nomos of the land' as the Greeks envisioned it is somehow related to the idea of a just distribution - very different, to be sure, from Schmitt's unfounded claims of any primordial 'taking of the land' or any other constitutive act of sovereign violence.

In order to develop a better understanding of 'the birth of nomos', Zartaloudis also dives deep into the Homeric use of nemein in a pastoral sense (to graze, to pasture). Given the crucial economic importance of cattle management for societies of the Late Bronze and Early Iron Ages, it makes sense that the act of governing is frequently associated with animal herding in an abundance of ancient texts from across the Mediterranean. In the Homeric epics, such metaphoric language is particularly evident in references to Agamemnon as 'shepherd of the people' (poimēn laōn). ${ }^{20}$ Other heroes are also frequently likened to herdsmen, with more or less interchangeable use of terms such as poimèn and boukolos, but also, and most interesting for our purposes, of nomeus as it is, of course, related to nemein and nomós. ${ }^{21}$ The image of the shepherd as a supreme leader can also be recognized in the epithet nomios as it is frequently used in combination with gods such as Apollo, Hermes and Zeus, characterizing them as the god-shepherds, so to speak, directing and managing the flock for which they are responsible. ${ }^{22}$

Philosophers such as Deleuze and Foucault have rightly pointed out that Homeric nomós - the noun associated with nemein in its pastoral sense - does not indicate a piece of land or a territory with clear boundaries, but, instead, an open space for pasturing without precise limits. ${ }^{23}$ If we can accept the general opinion of linguists that the later idea of nomos as law is not only nascent in distributive nemein, but is

20 See, e.g., Iliad 2.243; Iliad 4.413; Iliad 11.187; Iliad 11.202.

21 See, e.g., Iliad 17.63; Odyssey 17.214,

22 Pindar, Pythian 9.65. See also Michel Foucault, Security, Territory, Population, trans. Graham Burchell (London: Palgrave Macmillan, 2007), 188: 'The shepherd is the lawmaker insofar as he distributes food, directs the flock, indicates the right direction, and says how the sheep must mate so as to have good offspring. All this is the function of the shepherd who gives the law to his flock. Hence the title of Zeus as Nomios.'

23 Gilles Deleuze, Difference and Repetition, trans. Paul Patton (New York: Columbia University Press, 1994), 36 and 309, n. 6; Foucault, Security, Territory, Population, especially at the end of lecture 5 and the beginning of lecture 6 . 
also somehow related to pastoral nemein, nomeus and nomós and so forth, we may, yet again, come to conclusions that are quite contrary to Schmitt's account of nomos and its origins. For Schmitt, nomos in its original sense is, above all, a 'fence-word', denoting the occupation of a certain territory and its subsequent confinement within clear boundaries. ${ }^{24}$ It seems, however, that nómos is not linked to any violent 'taking of the land' at all, but, quite to the contrary, is at least partly related to the image of the shepherd's power as it is 'not exercised over a territory, but by definition over the flock as it moves from one place to another'. ${ }^{25}$

\section{Nomos, king of all}

In what follows, Zartaloudis moves on to post-Homeric nomos, starting out from nomos in Hesiod's didactic poetry up until the many uses of that word by the great classical tragedians. Of particular interest, perhaps, is Zartaloudis' treatment of an extant literary fragment in which Pindar - generally regarded as the greatest of the archaic Greek poets - famously proclaims that nomos is 'king of all'. The opening lines of the fragment can be rendered as follows: ${ }^{26}$

\section{Law, the king of all,}

of mortals and immortals,

guides them as it justifies the utmost violence with a powerful hand. I bring as witness the deeds of Heracles, for he drove Geryon's cattle to the Cyclopean portal of Eurystheus without punishment or payment.

\author{
Nomos ho pantōn basileus \\ thnatōn te kai athnatōn \\ agei dikaiōn to biaiotaton \\ hupertatai cheiri: tekmairomai \\ ergoisin Hērakleos \\ epei Gēruona boas \\ Kuklōpiōn epi prothurōn Eurustheos \\ anatei te kai apriatas elasen.
}

For Schmitt, the interpretation of these lines is clear. In service of Eurystheus, cruel king of Mycenean Tiryns, Heracles attacks and kills Geryon, a fearsome giant inhabiting a mythical island in the far west of the Mediterranean, steals his cattle and brings it to Eurystheus. Despite the transgressive nature of such acts, Heracles - the 'mythical founder of order' - creates law, turning chaos into order. ${ }^{27}$ As such, the Pindaric fragment would unveil nomos as 'the full immediacy of a legal power not mediated by laws'. The explanations of those who see in Pindaric nomos some higher objective or supreme norm at work are dismissed by Schmitt as 'idealistic-rhetorical paraphrases' that totally miss the point of law's indispensable groundwork of power and violence. ${ }^{28}$

24 Carrol Clarkson, 'The Obliging Etymology of "Nomos"', in Reading Modern Law, ed. Ruth Buchanan, Stewart Motha and Sundhya Pahuja (New York: Routledge, 2012), 165-177.

25 Deleuze, Difference and Repetition, 309 n. 6.

26 Text and translation have been adopted from William Race, Pindar (Cambridge MA: Harvard University Press, 1997), with slight adaptations.

27 Schmitt, Nomos of the Earth, 73. For Heracles as the violent founder of order, see also Walter Burkert, Greek Religion, trans. John Raffan (Cambridge MA: Harvard University Press, 1985), 208-212.

28 Schmitt, Nomos of the Earth, 73-74. 
The Pindaric fragment that has such a central place in Schmitt's reconstruction of the original meaning of nomos also plays an important role in the legal and political thought of Giorgio Agamben. In his view, Pindar deserves pride of place in the history of political thought as 'the first great theoretician of law and sovereignty'. ${ }^{29}$ Elaborating upon Schmitt's interpretation of the fragment, Agamben explains that Pindar deserves to be recognized as such because of clearly pointing out the intricate relation between the inside of the juridico-political order and its constitutive moment outside of it. For Agamben, it is only a small step from the Pindaric fragment to modern theorists of government such as Thomas Hobbes. With all their obvious differences taken for granted, both would have recognized the 'paradox of sovereignty' as it would lie at the basis of modern western law and politics, with the sovereign being located both within and outside of the legal order at the same time. ${ }^{30}$

What, then, should we make of such interpretations of the Pindaric fragment? To be sure, Heracles' behaviour while performing his great exploits is clearly at odds with normative standards as they usually apply within the cultured environment of the polis. Confronted with the naked forces of wild nature, the hero kills sacred beasts, challenges the gods and does many other things of questionable repute. Some added verses to the fragment that scholars have been able to reconstruct in the 1960s describe, among other things, how Heracles not only violently confronts Geryon, but also robs and slays Diomedes (king of Thrace), whose body he then feeds to his own man-eating mares. Thus, the added verses seem to corroborate Schmitt's view of Heracles as a violent creator of order, a 'hero god' who makes the world safe for well-ordered human life without himself being bound by the normative standards that usually apply within human societies. ${ }^{31}$

However, Heracles' liminal position partly outside the normative order of human society does not necessarily mean that we should think of his actions taking place in some normative vacuum and of nomos in the Pindaric fragment as 'an amoral, violent agent'. ${ }^{22}$ Such straightforward cynicism has been countered by those who point out that Heracles' behaviour may indeed be at odds with 'human law', but not necessarily also with 'divine law'. Hugh Lloyd-Jones, for example, contends that both Geryon and Diomedes should be recognized as the 'common enemies of gods and men'. By attacking them, he argues, Heracles was only promoting 'the justice of Zeus'. For Lloyd-Jones, therefore, it is clear that nomos in the Pindaric fragment should be understood as 'the law of Zeus' or 'the law of the universe'. ${ }^{33}$ In a similar vein, Marcello Gigante understands nomos in Pindar's fragment as 'il principio

29 Giorgio Agamben, Homo Sacer: Sovereign Power and Bare Life, trans. Daniel Heller-Roazen (Palo Alto: Stanford University Press, 1998), 24-28.

30 Agamben, Homo Sacer, 27.

31 Poulheria Kyriakou, 'The Violence of Nomos in Pindar fr. 169a' Materiali e discussioni per l'analisi dei testi classici 48 (2002): 205-206.

32 Loughlin, 'Nomos', 71.

33 Hugh Lloyd-Jones, 'Pindar Fr. 169', Harvard Studies in Classical Philology, 76 (1972): 56. 
assoluto della divinità' - a divine normative principle that overrides all human standards of behaviour. ${ }^{34}$

Should we now follow 'realist' interpretations of nomos in the Pindaric fragment such as those of Schmitt, Agamben and others? Or should we adhere to the 'idealism' of Gigante and Lloyd-Jones? Interestingly, as Zartaloudis also points out (p. 221), these two lines of interpretation do not necessarily exclude each other. For a proper understanding of Pindaric nomos, it seems important to read it against the background of a presocratic cosmology in which there is no such thing as any clear-cut distinction between facticity and normativity. In fact, Pindar's odes - and Greek literature more in general - abound with mythical stories that explain how the founding of a rightful political order is necessarily bound up with transgressive violence. Without such violence, humans would find themselves completely helpless when confronted with the naked forces of wild nature. Its clear exposure in Pindar's poetry merely seems to serve as an admonition that, in paradoxical fashion, just and well-ordered polis life is constantly at risk of falling prey to the very same forces of wild nature that help to sustain it. ${ }^{35}$

At any rate, in view of its wider historical and literary context, it seems safe to say that nomos in the Pindaric fragment should not be one-dimensionally understood in an abstract normative sense. The Stoic philosopher Chrysippus, for instance, certainly misreads it as he refers to the fragment in order to bolster his claim that nomos should be understood as some supreme standard of right and wrong, 'prescribing human beings what they should do and prohibiting them from what they should not do'. ${ }^{36}$ The cynical realism of those who refer to the Pindaric fragment as clear evidence of some principle of 'might makes right', however, should be dismissed as equally one-dimensional. It seems clear that nomos in the Pindaric fragment incorporates an element of transgressive violence that is necessarily bound up with any legal and political order. By itself, however, that does not make that order any less just. The explicit reference to the violent underpinnings of well-ordered polis life just seem to come as a reminder that, as Heraclitus famously puts it, 'all things come about by way of strife and necessity' and that 'war is the father of all things'. ${ }^{37}$

\section{The crisis of nomos}

Fitting its restricted purposes of genealogical description, Zartaloudis' new book largely leaves it to others to explore the importance of an advanced understanding of nomos for modern legal and political theory. Van der Walt's book on the concept of liberal democratic law is very different in that regard. That remarkable book

34 Marcello Gigante, NOMO $\Sigma$ BA $\Sigma I \Lambda E Y \Sigma$ (New York: Arno Press, 1979), 92.

35 See also Van den Berge, 'Law, King of All', 213-214; Kevin Crotty, Song and Action: The Victory Odes of Pindar (Baltimore: Johns Hopkins University Press, 1982), 105-108.

36 Chrysippus, fragment 314 (Arnim). The translation is quoted from Anthony Long and David Sedley, The Hellenistic Philosophers (Cambridge: Cambridge University Press, 1987), 432.

37 Heraclitus B80 (DK) and B53 (DK). 
developed from a series of class notes written for a first-year course in legal philosophy at the University of Luxembourg. Van der Walt's original educational purposes explain both the book's more or less chronological organization as well as its unusual scope, covering some of the most important developments in the history of western legal thinking from classical antiquity up to the present day. However, it is certainly much more than just another textbook in the history of legal philosophy. From beginning to end, the book develops an argument that clearly stands on its own, finally leading up to a plea for a renovated understanding of 'liberal democratic law' that would be much-needed in order to improve the chances of survival of that concept in today's turbulent world.

At the outset of his historical narrative, Van der Walt takes us back to what Michel Villey has identified as 'the crisis of nomos'. ${ }^{38}$ In archaic Greece, nomos consisted in the ensemble of customary rules and practices that informed a wide variety of aspects of life. It surely did not only pertain to the juridico-political sphere of conflict resolution and politics, but also to sacred rituals and other kinds of practices and routines - a point, in fact, that is made par excellence by Zartaloudis' extensive genealogical analysis of the term. In late classical Athens, however, the idea of nomos as a purportedly self-evident normative framework relying on custom and group morality finally collapsed in the wake of the rise of the sophists. In some of Plato's most famous dialogues, for instance, we read how opponents of Socrates such as Callicles and Thrasymachus argue that 'conventional justice' (nomos) is merely a device invented by the weak to curb the strong, rhetorically downplaying the fact that 'the justice of nature' (physis) only recognizes the right of the stronger. ${ }^{39}$

While instructing us what such sophistic thinking can amount to, Van der Walt draws specific attention to Thucydides' well-known dramatization of the negotiations between the Athenians and the citizens of the small island of Melos. ${ }^{40}$ In the Peloponnesian War between Athens and Sparta, the Melians preferred to stay neutral. The Athenians, however, demanded that they joined their side and pay tribute to Athens or face annihilation. In their conversation with the Melians as Thucydides reports it, the Athenian envoys completely disregard all normative standards as they are conventionally taken to apply in such matters. Whereas the Melians invoke the usual ethics of moderation and self-restraint, the Athenians candidly admit that they adhere to a cynical realism that only recognizes the principle of 'might makes right' as the eternal law (nomos) of nature. ${ }^{41}$ Forcing the Melians to comply, therefore, would only be the natural thing for the Athenians to do - just as their cynical understanding of nomos as nothing but the right of the

Michel Villey, La formation de la pensée juridique moderne (Paris: Montchretien, 1975), describing the collapse of 'la culte de nomos' as a result of 'la crise du Ve siècle' in chapter 1.

39 For the famous speech of Callicles, see Plato, Gorgias 482c-486d; for Thrasymachus defining justice as 'whatever is advantageous for the person who is stronger', see Plato, Republic 338c. For further references, see Bonazzi, The Sophists, 75-80 (on Callicles) and 80-83 (on Thrasymachus).

40 Thucydides, Histories 5.84-116.

41 Thucydides, Histories 5.105. 
stronger would ultimately legitimate the execution of all Melian men and the enslavement of women and children.

In Van der Walt's overall argument, the account of the Melian dialogue and the tragic fate of the Melians serves to warn us for an intellectual tradition of cynical realism that Van der Walt traces back to the sophists and would be echoed and continued in various ways by authors such as Machiavelli, Spinoza, Hobbes, Nietzsche and Schmitt. ${ }^{42}$ As Van der Walt has it, the atrocities at Melos clearly illustrate what such cynical realism can lead to as soon as it is put into political practice. But neither does he subscribe to the tradition of idealist natural law as it was originally developed by Plato, Aristotle and others in order to provide a way out of the nihilism of the sophists. According to Van der Walt, the idea of law as, somehow, a reflection of a good and objective natural order fits badly with modern pluralist societies in which it has become deeply controversial what such a good and objective order should exactly entail. In a way, therefore, the 'crisis of nomos' would last up until the present day, presenting us with a difficult choice between cynical realism and idealist normativism as two traditions of legal thought that are both deeply problematic.

\section{Human and divine nomos: Sophocles' Antigone}

In his extensive analysis of the intellectual foundations of western legal thought, Van der Walt also turns to what is perhaps the most classical of all classical texts on law and philosophy: Sophocles' Antigone. The plot may be familiar. After a terrible war, Creon - sole ruler of the city of Thebes - orders the corpse of Antigone's brother Polynices, who went to war against his own city, should be left unburied on the battlefield. Antigone violates Creon's command and buries Polynices after all, fulfilling the sacred duties generally understood to rest upon close relatives. Once Antigone is caught by a guard and brought before her ruler, Creon asks what has driven her to transgress the laws (nomoi) of the city. Antigone's answer to that question is quoted almost ad nauseam in modern textbooks on legal philosophy. 'Mortal as they are', Antigone argues, the laws promulgated by Creon are surely 'not strong enough to overrule the unwritten and unfailing ordinances of the gods (agrapta k'asphalē theōn nomima)', valid as these ordinances are 'not only today and yesterday, but for all time'. ${ }^{43}$

According to the standard textbook account, Sophocles' Antigone tells us the story of a young girl who rightly rebels against a criminal regime. ${ }^{44}$ Her claim of the superiority of divine law over human law is often associated with similar claims by modern heroes of civil disobedience such as Mahatma Gandhi and Martin Luther

44 See, e.g., Mark Tebbit, Philosophy of Law: An Introduction (New York: Routledge, 2017), 13-14. 
King. ${ }^{45}$ Generations of law students have thus been taught that Antigone is right and Creon is wrong. However, as Van der Walt rightly explains, a close inspection of the play teaches us quite something different. ${ }^{46}$ Admittedly, Creon's order to leave Polynices' corpse unburied is surely problematic. But there are also clear objections to Antigone's behaviour. In ancient eyes, her categorical rejection of a decree issued by Creon as the city's rightful ruler is at least as impious as that decree itself. And Antigone's behaviour becomes even more problematic as she remains completely fixated on her own exclusive rightness as the play progresses. As Castoriadis has once remarked, even if Antigone is right, her complete disregard for the legitimate arguments of her opponents still makes her wrong. ${ }^{47}$

What, then, can we learn from all this? According to Van der Walt, Sophocles' play teaches us that the inability to think beyond one's own self-righteousness ultimately comes with great misery - not only for Creon and Antigone themselves, but also for the entire city. Moral, political and legal conflict usually revolves around much more than just differences of opinion. Instead, it is usually also rooted in differences of conviction. As Van der Walt has it, there is no Hegelian synthesis, Rawlsian equilibrium or any other magical philosophical formula that may provide us with a way in which such differences can ultimately be overcome - not in Thebes as Sophocles describes it, but neither in our own contemporary world. That is why a stable political order inevitably relies on a 'constellation of compromises' (p. 63) that enables us to live together and to determine common schemes of action despite all these differences. Of course, such a constellation requires the ability of everyone involved to let go of one's own categorical beliefs and convictions - an ability that is clearly lacked by both Creon and Antigone.

\section{Nomos and the concept of liberal democratic law}

The connections drawn by Van der Walt between Sophocles' Antigone and the 'crisis of nomos' in late classical Athens on the one hand and contemporary problems of legal and political philosophy on the other are typical of his approach throughout the book as a whole. As Van der Walt claims, a thorough analysis of the intellectual foundations of law and liberal democracy is particularly urgent in a time of upcoming populism and political illiberalism. As 'an old undemocratic and illiberal Europe' (p. x) appears to rise from the graves, his book is informed by 'the concern that the age of liberal democracy will come to an end' (p. xi). In order to support its survival, it is Van der Walt's aim to make clear once more what a liberal democratic understanding of law is really about. Assessing the jurisprudential projects and positions of a wide range of historical and contemporary thinkers, Van der Walt paralleled with Martin Luther King's Letter from Birmingham Jail. See Pauline Westerman, Rechtsfilosofie (Heerlen: Open Universiteit, 1998), hoofdstuk 7.

46 See also Lukas van den Berge, 'Sophocles' Antigone and the Promise of Ethical Life. Tragic Ambiguity and the Pathologies of Reason', Law and Humanities 11 (2017): 205-227, with further references.

47 Cornelius Castoriadis, Ce que fait la Grèce (Paris: Seuil, 2008), 145. 
applies a method of 'distillation', finally arriving at a 'distilled concept of liberal democratic law' that should be cherished for the future (p. 13; p. 225-248).

Van der Walt's book does not only stand out by its extensive and original treatment of historical sources, but also by its broad philosophical scope as it engages with analytical as well as continental jurisprudence. Classical texts that receive specific attention include not only Sophocles' Antigone and Thucydides' Histories, but also Plato's Gorgias and Protagoras, Aristotle's Metaphysics and much more. Modern theorists that receive particular attention include Smend, Kelsen, Schmitt, Hart, Dworkin and Agamben. An important presupposition of Van der Walt's distillation process is that we need a concept of law that will remain to ensure peaceful co-existence in pluriform societies in which moral and political beliefs and convictions are deeply divergent. That is why any recourse to classical natural law theory would be uncalled for. But perhaps an even greater threat to the future of liberal democracy would be the acceptance of a cynical realism that rejects any appeal to common principles of justice altogether - as we have seen, we only have to reread Thucydides' account of what happened on the Greek island of Melos to be reminded of where such cynicism may lead to.

In the 'concept of liberal democratic law' that Van der Walt ultimately distils from an uncommon richness of sources, a 'dual relation to correctness' (p. 4-5) plays a vital role. On the one hand, as Van der Walt has it, liberal democrats - in the normative and definitive sense of the term - reject the Calliclean idea that principles of justice, reasonableness and equal respect are nothing more than rhetorical devices, designed to curtail the principle of 'might makes right' as the only true nomos of nature. On the other hand, liberal democrats are also cautious in claiming any direct insight into nomos as the good order of nature. As Van der Walt argues, these two divergent and irreconcilable conceptions of nomos should remain in the 'non-transparent and heavy metaphysical soup' (p. 13) from which the concept of liberal democratic law as he proposes it should be carefully extracted. What remains is an 'ethereal substance' (p. 13) that recognizes the value of ideals, but, at the same time, does not succumb to the temptation to insist that others should agree with those ideals - an important lesson, as we have seen, that Van der Walt derives from Sophocles' Antigone.

\section{Concluding remarks}

Thanos Zartaloudis' The Birth of Nomos and Johan van der Walt's The Concept of Liberal Democratic Law are both examples of excellent and thought-provoking scholarship. Both in their own right, they give proof of the enduring value of a deep engagement with ancient Greek sources for modern legal theory. Zartaloudis' investigations into the many different uses of nomos and cognate words in archaic and early classical sources throw important new light on a fundamental term in western legal history. Showing how the 'birth of nomos' is bound up with sacred rituals and other social practices, his book once again makes clear that law is a social and deeply cultural phenomenon. Moreover, Zartaloudis' book offers some 
important corrections of the speculative philology of Carl Schmitt and others who have been perhaps too creative in appropriating the ancient sources so as to fit their own theory. As Agamben's blurb on the back-cover has it, the book makes clear that 'we will need to rethink all the themes that our ethical and political tradition has gathered around the word "law"' and perhaps that is not even an exaggeration.

The importance of Zartaloudis' new book stands out in even clearer fashion when it is read in conjunction with Johan van der Walt's The Concept of Liberal Democratic Law. As Van der Walt's book makes clear, the ancient history of nomos is not only interesting by itself, but also of great significance to the development of legal and political theory up to the present day. Expertly drawing a wide range of connections across the ages, Van der Walt successfully exposes how western legal thinking relies for an important part on an ancient metaphysics that understands nomos either as a reflection of some good natural order or as the forceful imposition of arbitrary order on natural anarchy. Arguing for a serious reconsideration of such metaphysics, Van der Walt continues, in a way, a rich and diverse intellectual tradition that includes all those who have embraced the idea that, while confronting contemporary problems of law and philosophy, it is of crucial importance to re-investigate the ancient Greek tradition and rethink our relation to it. One thing seems for sure: we cannot permit ourselves to leave the ancient Greeks completely behind us. 